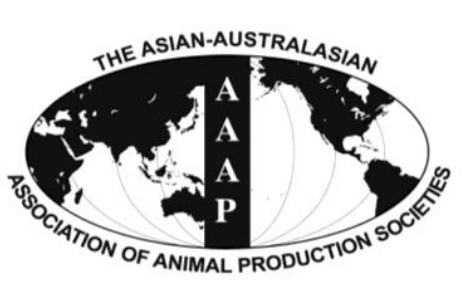

Open Access

Asian Australas. J. Anim. Sci.

Vol. 27, No. 3 : 439-446 March 2014

http://dx.doi.org/10.5713/ajas.2013.13401

www.ajas.info

pISSN 1011-2367 elSSN 1976-5517

\title{
Data Build-up for the Construction of Korean Specific Greenhouse Gas Emission Inventory in Livestock Categories
}

\author{
S. G. Won, W. S. Cho, J. E. Lee, K. H. Park, and C. S. Ra* \\ Department of Animal Life System, Kangwon National University, \\ Hyoja 2, 192-1, Chuncheon 200-701, Korea
}

\begin{abstract}
Many studies on methane $\left(\mathrm{CH}_{4}\right)$ and nitrous oxide $\left(\mathrm{N}_{2} \mathrm{O}\right)$ emissions from livestock industries have revealed that livestock production directly contributes to greenhouse gas $(\mathrm{GHG})$ emissions through enteric fermentation and manure management, which causes negative impacts on animal environment sustainability. In the present study, three essential values for GHG emission were measured; i.e., i) maximum $\mathrm{CH}_{4}$ producing capacity at mesophilic temperature $\left(37^{\circ} \mathrm{C}\right)$ from anaerobically stored manure in livestock category $\left(\mathrm{B}_{0, \mathrm{KM}}\right.$, Korean livestock manure for $\left.\mathrm{B}_{0}\right)$, ii) $\mathrm{EF}_{3(\mathrm{~s})}$ value representing an emission factor for direct $\mathrm{N}_{2} \mathrm{O}$ emissions from manure management system $S$ in the country, $\mathrm{kg} \mathrm{N}_{2} \mathrm{O}-\mathrm{N} \mathrm{kg} \mathrm{N} \mathrm{N}^{-1}$, at mesophilic $\left(37^{\circ} \mathrm{C}\right)$ and thermophilic $\left(55^{\circ} \mathrm{C}\right)$ temperatures, and iii) $\mathrm{N}_{\mathrm{ex}(\mathrm{T})}$ emissions showing annual $\mathrm{N}$ excretion for livestock category $T, \mathrm{~kg} \mathrm{~N}$ animal ${ }^{-1} \mathrm{yr}^{-1}$, from different livestock manure. Static incubation with and without aeration was performed to obtain the $\mathrm{N}_{2} \mathrm{O}$ and $\mathrm{CH}_{4}$ emissions from each sample, respectively. Chemical compositions of pre- and post- incubated manure were analyzed. Contents of total solids (\% TS) and volatile solid (\% VS), and the ratio of carbon to nitrogen $(\mathrm{C} / \mathrm{N})$ decrease significantly in all the samples by $\mathrm{C}$-containing biogas generation, whereas moisture content $(\%)$ and $\mathrm{pH}$ increased after incubation. A big difference of total nitrogen content was not observed in pre- and post-incubation during $\mathrm{CH}_{4}$ and $\mathrm{N}_{2} \mathrm{O}$ emissions. $\mathrm{CH}_{4}$ emissions $\left(\mathrm{g} \mathrm{CH}_{4} \mathrm{~kg} \mathrm{VS}^{-1}\right.$ ) from all the three manures (sows, layers and Korean cattle) were different and high $\mathrm{C} / \mathrm{N}$ ratio resulted in high $\mathrm{CH}_{4}$ emission. Similarly, $\mathrm{N}_{2} \mathrm{O}$ emission was found to be affected by $\% \mathrm{VS}, \mathrm{pH}$, and temperature. The $\mathrm{B}_{0, \mathrm{KM}}$ values for sows, layers, and Korean cattle obtained at $37^{\circ} \mathrm{C}$ are $0.0579,0.0006$, and $0.0828 \mathrm{~m}^{3} \mathrm{CH}_{4} \mathrm{~kg} \mathrm{VS}^{-1}$, respectively, which are much less than the default values in IPCC guideline (GL) except the value from Korean cattle. For sows and Korean cattle, $\mathrm{N}_{\mathrm{ex}(\mathrm{T})}$ values of 7.67 and $28.19 \mathrm{~kg} \mathrm{~N} \mathrm{yr}^{-1}$, respectively, are 2.5 fold less than those values in IPCC GL as well. However, $\mathrm{N}_{\mathrm{ex}(\mathrm{T})}$ value of layers $0.63 \mathrm{~kg} \mathrm{~N} \mathrm{yr}^{-1}$ is very similar to the default value of $0.6 \mathrm{~kg} \mathrm{~N} \mathrm{yr}^{-1}$ in IPCC GLs for National greenhouse gas inventories for countries such as South Korea/Asia. The $\mathrm{EF}_{3(\mathrm{~s})}$ value obtained at $37^{\circ} \mathrm{C}$ and $55^{\circ} \mathrm{C}$ were found to be far less than the default value. (Key Words: Greenhouse Gases, Livestock, Manure, Methane, Nitrous Oxide)
\end{abstract}

\section{INTRODUCTION}

Worldwide agricultural sectors play a significant role in greenhouse effect (Amon et al., 2001). Greenhouse gases (GHG) emission from agricultural sectors include livestock rearing, rice cultivation, crop residue burning and agricultural soil (Gupta et al., 2007). According to the improvement of living standards and the changes of dietary life in recent years, the total livestock population has

\footnotetext{
* Corresponding Author: C. S Ra. Tel: +82-33-250-8618, Fax: +82-33-251-7719, E-mail: changsix@kangwon.ac.kr Submitted Jul. 2, 2013; Accepted Aug. 24, 2013; Revised Dec. 23, 2013
}

rapidly increased accompanying the amount of its manure (Lu et al., 2008; Wang et al., 2010). Livestock production with animals directly contributes to emissions through enteric fermentation and manure management. Methane is produced during the normal digestive processes of animals. Ruminant animals are the major contributors to methane emission (about two thirds of $\mathrm{CH}_{4}$ emissions of $6.8 \mathrm{Tg} \mathrm{yr}^{-1}$ in the EU; Moss et al., 2000) due to the type of digestive process by which carbohydrates are broken down by microorganisms and methane is released as a by-product of enteric fermentation (Stevens and Hume, 1995). Nonruminant animals also produce some methane, although not as much as ruminants due to the limitation of enteric 
fermentation occurrence in the post-gastric compartment such as cecum and large intestines (Robinson et al., 1989; Sukahara and Ushida, 2000). Methane $\left(\mathrm{CH}_{4}\right)$ increased from 715 parts per billion by volume (ppbv, 1,988 $\mathrm{Tg}$ ) to 1,774 ppbv (4,932 Tg); and nitrous oxide $\left(\mathrm{N}_{2} \mathrm{O}\right)$ from 270 ppbv (1,296 Tg) to $319 \mathrm{ppbv}(1,531 \mathrm{Tg})$ between 1750 and 2005 (4.8 Tg N = 1 ppbv, $2.78 \mathrm{Tg} \mathrm{CH}_{4}=1 \mathrm{ppbv}$, and 2.13 Gt $\mathrm{C}=1$ ppmv; IPCC 2001, 2007). Anthropogenic processes are estimated to be responsible for $55 \%$ to $70 \%$ of the global $\mathrm{CH}_{4}$ emissions of $600 \mathrm{Tg} \mathrm{yr}^{-1}$ into the atmosphere. The global warming potential of $\mathrm{CH}_{4}$ and $\mathrm{N}_{2} \mathrm{O}$ is approximately 21- and 310-fold, respectively higher than that of $\mathrm{CO}_{2}$ (IPCC, 1996). Of total global anthropogenic emissions of GHGs in 2005, agriculture accounted for about $58 \%\left(2.8 \mathrm{Gt} \mathrm{CO}_{2}\right.$-eq $\left.\mathrm{yr}^{-1}\right)$ of $\mathrm{N}_{2} \mathrm{O}$ and about $47 \%(3.3 \mathrm{Gt}$ $\mathrm{CO}_{2}$-eq $\mathrm{yr}^{-1}$ ) of $\mathrm{CH}_{4}$ (IPCC, 2007). With a mean annual emission rate of about $60 \mathrm{Mt} \mathrm{CO}_{2}$-eq $\mathrm{yr}^{-1}$ between 1990 and 2005, global agricultural $\mathrm{CH}_{4}$ and $\mathrm{N}_{2} \mathrm{O}$ emissions increased by nearly $17 \%$ (IPCC, 2007). Globally, livestock-related $\mathrm{N}_{2} \mathrm{O}$ and $\mathrm{CH}_{4}$ emissions are about $1.8 \mathrm{Gt} \mathrm{CO}_{2}$-eq $\mathrm{yr}^{-1}$ and $2.17 \mathrm{Gt} \mathrm{CO}_{2}$-eq $\mathrm{yr}^{-1}$ (1.8 from ruminants+0.37 from manure, respectively) (Steinfeld et al., 2006). Production and emission of $\mathrm{CH}_{4}$ and $\mathrm{N}_{2} \mathrm{O}$ from manure does not depend only upon digestibility and composition of feed, species of animals, and their physiology but also upon manure management practices and environmental conditions such as sunlight, temperature, precipitation, wind, etc. (Yamulki et al., 1999; Brown et al., 2002; Park et al., 2006, Gupta et al., 2007).

Nitrous oxide is produced via the nitrificationdenitrification process that occurs from nitrogen sources in manure. The majority of nitrogen sources in manure are present in ammonia form and nitrification occurs aerobically and converts ammonia-N into nitrate, while denitrification occurs anaerobically, and converts the nitrate to $\mathrm{N}_{2} \mathrm{O}$. Temperature, $\mathrm{pH}$, biochemical oxygen demand, and nitrogen concentration affect $\mathrm{N}_{2} \mathrm{O}$ generation (Sorai et al., 2007). Increasing aeration initiates the nitrification reactions, followed by the denitrification under anoxic condition, which causes $\mathrm{N}_{2} \mathrm{O}$ generation. Since fresh dung and slurry has sufficient alkalinity and stay at near neutral $\mathrm{pH}, \mathrm{N}_{2} \mathrm{O}$ production may be presumably expected to increase with increasing aeration. However, $\mathrm{N}_{2} \mathrm{O}$ emissions from animal manure are not clear since there is not enough quantitative data to derive a relationship between the degree of aeration and $\mathrm{N}_{2} \mathrm{O}$ emissions (Sorai et al., 2007).

GHG emission values from livestock industry are separated into two categories; i) enteric fermentation and ii) manure treatment processes. Many studies for GHG emissions have been carried out with respect to the enteric fermentation but GHG emission from manure treatment processes has been rarely studied (Wang and Huang, 2004). Regional-specific emission inventory for $\mathrm{CH}_{4}, \mathrm{~N}_{2} \mathrm{O}$ and
$\mathrm{NH}_{3}$ via animal faming was reported in south, southeast and east Asia (Yamaji et al., 2003) and the US is first to develop the $\mathrm{B}_{0}$ values in livestock categories. However, there is no useful documents about $\mathrm{B}_{0}$ on the development of the GHG emission values from other countries (Safley, 1992, EPA/400/1-91/048, Global Methane Emissions from Livestock and Poultry Manure). Japan has developed default GHG emission values based on IPCC 1996 (National Greenhouse Gas Inventory Report of Japan, 2006). Further, New Zealand also has their own GHG emission values but only for grazing animals like milking cow, beef, lamb, and deer. However, GHG emission values for other types of livestock are estimated based on IPCC GL. Due to a lack of the information about $\mathrm{CH}_{4}$ and $\mathrm{N}_{2} \mathrm{O}$ emissions from manure management system of South Korea/Asia, some previous emission inventories in Asia were prepared using IPCC default emission factors (Garg et al., 2001; Yamaji et al., 2003). There is no GHG emission values in any national report from Korea though the study on the development of country specific values was started in 2009. IPCC recommends using IPCC guideline (GL) 1996, 2001, and 2006 to develop greenhouse gas (GHG) emissions for country GHG emission statistics. If countries have their own specific data, it would be preferred over the general GHG emission values from IPCC which has large uncertainties. In order to develop country specific GHG emission factors, it is required to ensure data accumulation for 3 years at least (IPCC, 1996). Therefore, this study aims to obtain the i) $\mathrm{B}_{0, \mathrm{KM}}$ of anaerobically stored manure in Korea, ii) $\mathrm{EF}_{3(\mathrm{~s})}$ from aerobically treated stored manure, and iii) $\mathrm{N}_{\mathrm{ex}(\mathrm{T})}$ values, from the different livestock categories in Korea.

\section{MATERIALS AND METHODS}

\section{Experimental apparatus}

House-made test set by modifying EPA method 18 (1981) and method 0040 (1998) was prepared for this study. A high density polyethylene sealable container of dimensions $26.2 \mathrm{~cm} \times 20.3 \mathrm{~cm} \times 27.2 \mathrm{~cm}$ (bottom diameter $\times$ top diameter $\times$ height) was used in the entire experiment. A polyethylene connector with a pipe thread and a hose barb $(0.48 \mathrm{~cm})$ was mounted firmly to the container's lid. A sure seal was achieved by use of a silicon sealant. A heavy rubber hose $(0.48 \mathrm{~cm}$ i.d.) was connected to the incubator container and the other end was connected to a Tedlar gas collection bag (Nouchi et al., 1990; Cho et al., 2012). Tedlar bags were inspected regularly. For $\mathrm{N}_{2} \mathrm{O}$ measurement, an air stone was placed at the bottom of incubation vessel and air was supplied through an extra pipe. Because manure in a heap is turned at regular interval ( 2 or 3 times $\mathrm{d}^{-1}$ ) and air is trapped in the manure during each turn, aeration was supplied into the incubation vessel throughout the 
experiment in order to mimic the manure management practices.

\section{Livestock manure}

The manure (dung and urine) from three different animal categories (i.e. sow, layers and Korean cattle) were collected from the farm operated by Kangwon National University in South Korea, where all livestock were being raised according to the Korean Feeding Standard. For each set of experiments fresh manure were collected and immediately processed.

\section{Procedure}

In all the trials for $\mathrm{CH}_{4}$ and $\mathrm{N}_{2} \mathrm{O}$ measurement, manure samples $(1 \mathrm{~kg})$ were mixed with $250 \mathrm{~g}$ of plastic beads $(5$ $\mathrm{mm}$ diameter) to avoid entrapment of gases produced during incubation, and transferred in incubator vessel. For $\mathrm{B}_{0}$ measurement, mixed liquor from a full-scale mesophilic anaerobic digester was used as inoculums at the rate of 250 $\mathrm{mL} / \mathrm{kg}$ manure. Pure $\mathrm{N}_{2}$ gas was sparged into the vessel in order to form anaerobic condition and the vessel was placed in water baths maintaining temperature at $37^{\circ} \mathrm{C}$ until no more gas produced. A control vessel contained only the same amount of mixed liquor and was exposed to the same condition of other testing manure vessels.

Testing of aeration cycles for maximum $\mathrm{N}_{2} \mathrm{O}$ emission was carried out using sow manure. Manure was then incubated at $37^{\circ} \mathrm{C}$ and $2 \mathrm{~L}$ air at a rate of $500 \mathrm{~mL} \mathrm{~min}^{-1}$ was given into the incubation vessel at different time intervals (2, $4,6,8,12$, and $16 \mathrm{~h}$ ) until no more gas produced.

For $\mathrm{N}_{2} \mathrm{O}$ emission from sow, layers and Korean cattle, each fresh manure sample was added in incubating vessels. Incubation was performed at mesophilic $\left(37^{\circ} \mathrm{C}\right)$ and thermophilic $\left(55^{\circ} \mathrm{C}\right)$ temperatures until no more gas collected. All gas samples in Tedlar bags were analyzed in triplicate.

\section{Calculation of emission factors}

For the estimation of $\mathrm{CH}_{4} \quad \mathrm{EF}_{(\mathrm{T})}$ for manure (liquid/slurry), we measured the $\mathrm{B}_{0(\mathrm{~T})}$ value, according to IPCC, 2006 Tier 2 emission factors for manure management practices equation,

$$
\begin{aligned}
\mathrm{EF}_{(\mathrm{T})}= & \left(\mathrm{VS}_{(\mathrm{T})} \times 365\right) \\
& \times\left[\mathrm{B}_{\mathrm{o}(\mathrm{T})} \times 0.67 \mathrm{~kg} / \mathrm{m}^{3} \times \sum_{\mathrm{S}, \mathrm{k}} \frac{\mathrm{MCF}_{\mathrm{s}, \mathrm{k}}}{100} \times \mathrm{MS}_{(\mathrm{T}, \mathrm{S}, \mathrm{k})}\right]
\end{aligned}
$$

where, $\mathrm{EF}_{(\mathrm{T})}$ : annual $\mathrm{CH}_{4}$ emission factor for livestock category $\mathrm{T}, \mathrm{kg} \mathrm{CH}_{4}$ animal $^{-1} \mathrm{yr}^{-1} ; \mathrm{VS}_{(\mathrm{T})}$ : daily volatile solid excreted for livestock category $\mathrm{T}, \mathrm{kg}$ dry matter animal ${ }^{-1} \mathrm{~d}^{-1}$; 365: basis for calculating annual VS production days $\mathrm{yr}^{-1}$; $\mathrm{B}_{0(\mathrm{~T})}$ : maximum $\mathrm{CH}_{4}$ producing capacity for manure produced by livestock category $\mathrm{T}, \mathrm{m}^{3} \mathrm{CH}_{4} \mathrm{~kg}^{-1}$ of VS excreted; 0.67: conversion factor of $\mathrm{m}^{3} \mathrm{CH}_{4}$ to kilogram $\mathrm{CH}_{4} ; \mathrm{MCF}_{(\mathrm{S}, \mathrm{k})}$ : $\mathrm{CH}_{4}$ conversion factor for each manure management system $\mathrm{S}$ by climate region $\mathrm{k}, \%$ and $\mathrm{MS}_{(\mathrm{T}, \mathrm{S}, \mathrm{k})}$ : fraction of livestock category T's manure handled using manure management systems $\mathrm{S}$ in climate region $\mathrm{k}$, dimensionless.

For the calculating the direct $\mathrm{N}_{2} \mathrm{O}(\mathrm{kg})$ emissions from manure management in the country, according to equation Tier 1, IPCC, 2006 GLs, we measured the emission factor $\left(\mathrm{EF}_{3(\mathrm{~s})}\right)$ and annual average $\mathrm{N}$ excretion per head of species/category $\left(\mathrm{N}_{\mathrm{ex}(\mathrm{T})}\right)$.

$$
\mathrm{N}_{2} \mathrm{O}_{\mathrm{D}(\mathrm{mm})}=\left\{\sum_{\mathrm{S}}\left[\sum_{T}\left(\mathrm{~N}_{(\mathrm{T})} \times \mathrm{N}_{\mathrm{ex}(\mathrm{T})} \times \mathrm{MS}_{(\mathrm{T}, \mathrm{S})}\right] \times \mathrm{EF}_{3(\mathrm{~S})}\right\} \times \frac{44}{28}\right.
$$

where, $\mathrm{N}_{2} \mathrm{O}_{D(m m)}$ : direct $\mathrm{N}_{2} \mathrm{O}$ emissions from manure management in the country, $\mathrm{kg} \mathrm{N}_{2} \mathrm{O} \mathrm{yr}^{-1} ; \mathrm{N}_{(\mathrm{T})}$ : number of head of livestock species/category $T$ in the country; $\mathrm{N}_{\mathrm{ex}(\mathrm{T})}$ : annual average $\mathrm{N}$ excretion per head of species/category $T$ in the country, $\mathrm{kg} \mathrm{N}$ animal ${ }^{-1} \mathrm{yr}^{-1} ; \mathrm{MS}_{(\mathrm{T}, \mathrm{S})}$ : fraction of total annual nitrogen excretion for each livestock species/category $T$ that is managed in manure management system $S$ in the country, dimensionless; $\mathrm{EF}_{3(\mathrm{~S})}$ : emission factor for direct $\mathrm{N}_{2} \mathrm{O}$ emissions from manure management

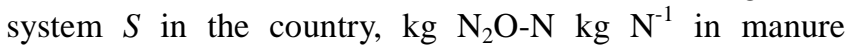
management system $S$; $\mathrm{S}$ : manure management system; T: species/category of livestock; 44/28: conversion of $\left(\mathrm{N}_{2} \mathrm{O}-\mathrm{N}\right)_{(\mathrm{mm})}$ emissions to $\mathrm{N}_{2} \mathrm{O}_{(\mathrm{mm})}$ emissions.

\section{Analytical methods}

Gas measurement: The gas volume was measured by drawing the gas out of the Tedlar bag and passing it through MP-E30-Minipump (Sibata-8086-030). For $\mathrm{CH}_{4}$ and $\mathrm{N}_{2} \mathrm{O}$ measurement, a total of $60 \mathrm{~mL}$ gas was withdrawn using a 3 -way plastic syringe of $60 \mathrm{~mL}$ and analyzed using 'Gas Chromatograph' (Varian 450) equipped with FID (flame ionized detector), ECD (electron capture detector), and TCD (thermal conductivity detector) and five stainless steel columns packed with Hayesep Q (80/100, $0.5 \mathrm{~m} \times 1 / 8$ " SS); Porapak-Q (80/100; $2 \mathrm{~m} \times 1 / 8$ " SS); Porapak-Q (80/100; 0.5 $\mathrm{m} \times 1 / 8$ " SS); Porapak-Q (80/100; $3 \mathrm{~m} \times 1 / 8$ " SS) and Porapak-Q $(80 / 100 ; 0.5 \mathrm{~m} \times 1 / 8$ " SS). The oven temperature was set at $70^{\circ} \mathrm{C}$, while the temperature for FID, TCD, and ECD was $250^{\circ} \mathrm{C}, 220^{\circ} \mathrm{C}$, and $350^{\circ} \mathrm{C}$, respectively. The flow rate of $\mathrm{N}_{2}$ (carrier gas) and $\mathrm{H}_{2}$ was $30 \mathrm{~mL} \mathrm{~min}^{-1}$, air was 300 $\mathrm{mL} \mathrm{m^{-1 }}$, whereas for helium as makeup gas was $10 \mathrm{~mL}$ $\min ^{-1}$. For ECD and TCD, makeup gases were $\mathrm{N}_{2}(10 \mathrm{~mL}$ $\left.\min ^{-1}\right)$ and $\mathrm{He}\left(10 \mathrm{~mL} \mathrm{~min}{ }^{-1}\right)$, respectively. $\mathrm{CH}_{4}(2.1 \mu \mathrm{mol}$ $\left.\mathrm{mol}^{-1}\right)$ and $\mathrm{N}_{2} \mathrm{O}\left(1.0 \mu \mathrm{mol} \mathrm{mol}^{-1}\right)$ calibrations gas standards (Research Institute of Gas Analytical Science) were used. The peak of $\mathrm{CH}_{4}$ and $\mathrm{N}_{2} \mathrm{O}$ identified on the basis of retention time was 1.15 and $4.4 \mathrm{~min}$, respectively and the 
Table 1. Characteristics of manure from different animal category stored under anaerobic conditions

\begin{tabular}{|c|c|c|c|c|c|c|}
\hline \multirow{3}{*}{ Parameters } & \multicolumn{6}{|c|}{ Livestock manure } \\
\hline & \multicolumn{2}{|c|}{ Sow } & \multicolumn{2}{|c|}{ Layers } & \multicolumn{2}{|c|}{ Korean cattle } \\
\hline & Fresh & After incubation & Fresh & After incubation & Fresh & After incubation \\
\hline $\mathrm{TN}, \%$ & $1.01 \pm 0.12^{\mathrm{a}}$ & $0.96 \pm 0.02^{\mathrm{a}}$ & $2.28 \pm 0.41^{\mathrm{b}}$ & $2.09 \pm 0.12^{\mathrm{b}}$ & $0.38 \pm 0.02^{\mathrm{c}}$ & $0.41 \pm 0.09^{\mathrm{c}}$ \\
\hline $\mathrm{TS}, \%$ & $31.09 \pm 0.32^{\mathrm{a}}$ & $28.76 \pm 0.42^{\mathrm{b}}$ & $24.40 \pm 0.35^{\mathrm{c}}$ & $16.68 \pm 0.12^{\mathrm{d}}$ & $21.52 \pm 0.17^{\mathrm{e}}$ & $21.44 \pm 0.33^{\mathrm{e}}$ \\
\hline $\mathrm{MC}, \%$ & $68.91 \pm 0.19^{\mathrm{a}}$ & $71.24 \pm 0.42^{\mathrm{b}}$ & $75.60 \pm 0.35^{\mathrm{c}}$ & $83.31 \pm 0.12^{\mathrm{d}}$ & $78.48 \pm 0.17^{\mathrm{e}}$ & $78.56 \pm 0.33^{\mathrm{e}}$ \\
\hline $\mathrm{VS}, \%$ & $25.12 \pm 0.19^{\mathrm{a}}$ & $22.54 \pm 0.39^{\mathrm{b}}$ & $17.64 \pm 0.65^{\mathrm{c}}$ & $10.75 \pm 0.10^{\mathrm{d}}$ & $17.00 \pm 0.07^{\mathrm{c}}$ & $16.37 \pm 0.30^{c}$ \\
\hline $\mathrm{pH}$ & $6.89 \pm 0.02^{\mathrm{a}}$ & $7.29 \pm 0.03^{\mathrm{a}}$ & $6.38 \pm 0.02^{\mathrm{ab}}$ & $7.81 \pm 0.07^{\mathrm{ac}}$ & $7.16 \pm 0.01^{\mathrm{ac}}$ & $8.11 \pm 0.10^{\mathrm{ac}}$ \\
\hline $\mathrm{C} / \mathrm{N}$ ratio & $13.94 \pm 1.57^{\mathrm{a}}$ & $13.05 \pm 0.17^{\mathrm{a}}$ & $4.40 \pm 0.85^{\mathrm{a}}$ & $2.86 \pm 0.18^{\mathrm{b}}$ & $24.90 \pm 1.25^{\mathrm{c}}$ & $22.79 \pm 4.19^{c}$ \\
\hline
\end{tabular}

Contents in \% are based on a wet basis.

$\mathrm{TN}=$ Total nitrogen; $\mathrm{TS}=$ Total solids; $\mathrm{MC}=$ Moisture content; $\mathrm{VS}=$ Volatile solids; $\mathrm{C} / \mathrm{N}=$ Carbon to nitrogen $\pm \pm=$ Standard deviation $(\mathrm{n}=3)$.

${ }^{\mathrm{a}-\mathrm{f}}$ Means with unequal superscripts in a row shows significance difference at $\mathrm{p}<0.05$.

response factor obtained was used to calculate parts per million of each gas in the sample.

Chemical composition analysis of manure: Each manure sample was analyzed for $\mathrm{pH}$, total solids (TS), total volatile solids (TVS), total soluble organic carbon (TOCs), total nitrogen (TN) and $\mathrm{C} / \mathrm{N}$ (carbon to nitrogen) ratio by using standard protocol before and after incubation (APHA, 2005).

\section{Statistical analysis}

The significant differences of manure characteristics before and after incubation within each livestock category were statistically analyzed by one-way ANOVA (analysis of variance) at $\mathrm{p}<0.05$ and multiple comparisons were performed with Tukey's test in SYSTAT version 6.0.1 (1996, SPSS Inc.).

\section{RESULTS AND DISCUSSION}

\section{Manure characteristics}

As expected, the fresh manure had different characteristics according to the different excretory pattern of the animals (Petersen et al., 1998; Smith et al., 2001; Loyon et al., 2008). The layer manure had higher levels of total nitrogen $(2.28 \%)$, which is over two and seven times higher than sow $(1.01 \%)$ and the Korean cattle $(0.38 \%)$, respectively (Table 1), and in corroboration with Loyon et al. (2008). Similarly, \% TS and moisture content (\%) significantly differs in all the categories of livestock manure. However, \% VS of layers (17.64\%) and the Korean cattle $(17.00 \%)$ do not show any significant difference $(\mathrm{p}<0.05)$. $\mathrm{pH}$ of Korean cattle manure (7.16) was higher than those of sow (6.89) and layers (6.38). C/N of Korean cattle was higher (31.01), followed by sow (18.60) and layers (13.19).

Manure collected for $\mathrm{N}_{2} \mathrm{O}$ emission experiments after 120 days showed similar patterns of $\% \mathrm{TN}, \% \mathrm{TS}, \mathrm{C} / \mathrm{N}$ ratio and moisture content (\%) as discussed above. However, the significant difference $(\mathrm{p}<0.05)$ of $\%$ VS was observed in layers and Korean cattle manure (Table 2).

After an incubation period of 30 days at $37^{\circ} \mathrm{C}$ under anaerobic condition, \% TN was not changed considerably in sow, layers and Korean cattle manure (Table 1). In contrast, \% TS was significantly $(\mathrm{p}<0.05)$ decreased in sow and layers manures. However, \% TS of Korean cattle was not changed during the experimental period. The $\% \mathrm{VS}$ and $\mathrm{C} / \mathrm{N}$ ratio in all the manure samples were significantly decreased $(\mathrm{p}<0.05)$ after the incubation, which were reported by Kulling et al. (2003) showing significant decrease in $\mathrm{C} / \mathrm{N}$ ratio of liquid and farmyard dairy manure after a storage period of 5 weeks.

After an incubation period until no more gas produced at $37^{\circ} \mathrm{C}$ and $55^{\circ} \mathrm{C}$ with $2 \mathrm{~h}$ aeration interval, no significant change in $\% \mathrm{TN}$ of three livestock manure was observed at

Table 2. Characteristics of manure from different animal category stored for $\mathrm{N}_{2} \mathrm{O}$ emission

\begin{tabular}{|c|c|c|c|c|c|c|c|c|c|}
\hline \multirow{3}{*}{ Parameters } & \multicolumn{9}{|c|}{ Livestock manure } \\
\hline & \multicolumn{3}{|c|}{ Sow } & \multicolumn{3}{|c|}{ Layers } & \multicolumn{3}{|c|}{ Korean cattle } \\
\hline & Fresh & $37^{\circ} \mathrm{C}$ & $55^{\circ} \mathrm{C}$ & Fresh & $37^{\circ} \mathrm{C}$ & $55^{\circ} \mathrm{C}$ & Fresh & $37^{\circ} \mathrm{C}$ & $55^{\circ} \mathrm{C}$ \\
\hline $\mathrm{TN}, \%$ & $0.87 \pm 0.06^{\mathrm{a}}$ & $1.40 \pm 0.06^{\mathrm{a}}$ & $1.49 \pm 0.08^{\mathrm{a}}$ & $2.39 \pm 0.27^{\mathrm{b}}$ & $1.53 \pm 0.04^{\mathrm{b}}$ & $1.23 \pm 0.04^{\mathrm{b}}$ & $0.43 \pm 0.02^{\mathrm{c}}$ & $0.44 \pm 0.02^{\mathrm{c}}$ & $0.30 \pm 0.05^{\mathrm{c}}$ \\
\hline $\mathrm{TS}, \%$ & $31.09 \pm 0.18^{\mathrm{a}}$ & $22.89 \pm 0.30^{\mathrm{b}}$ & $23.34 \pm 1.89^{\mathrm{b}}$ & $18.05 \pm 0.19^{c}$ & $14.49 \pm 0.15^{\mathrm{d}}$ & $15.77 \pm 0.23^{\mathrm{d}}$ & $22.20 \pm 0.14^{\mathrm{b}}$ & $14.85 \pm 0.44^{\mathrm{d}}$ & $13.95 \pm 0.13^{\mathrm{d}}$ \\
\hline $\mathrm{MC}, \%$ & $68.84 \pm 0.18^{\mathrm{a}}$ & $77.73 \pm 0.30^{\mathrm{b}}$ & $78.03 \pm 0.89^{b}$ & $81.60 \pm 0.19^{c}$ & $85.31 \pm 0.15^{\mathrm{d}}$ & $84.25 \pm 0.23^{\mathrm{d}}$ & $77.52 \pm 0.14^{\mathrm{b}}$ & $85.95 \pm 0.44^{\mathrm{d}}$ & $87.78 \pm 0.13^{d}$ \\
\hline VS, \% & $25.09 \pm 0.11^{\mathrm{a}}$ & $13.97 \pm 0.34^{\mathrm{b}}$ & $14.23 \pm 0.63^{\mathrm{b}}$ & $12.43 \pm 0.16^{\mathrm{d}}$ & $8.46 \pm 0.09^{\mathrm{e}}$ & $9.02 \pm 0.02^{\mathrm{e}}$ & $17.85 \pm 0.17^{\mathrm{c}}$ & $9.54 \pm 0.39^{\mathrm{de}}$ & $9.71 \pm 0.09^{\mathrm{e}}$ \\
\hline $\mathrm{pH}$ & $6.91 \pm 0.01^{\mathrm{a}}$ & $7.64 \pm 0.01^{\mathrm{b}}$ & $8.13 \pm 0.07^{\mathrm{b}}$ & $7.25 \pm 0.02^{\mathrm{ab}}$ & $9.24 \pm 0.02^{\mathrm{c}}$ & $9.01 \pm 0.05^{\mathrm{c}}$ & $6.81 \pm 0.02^{\mathrm{a}}$ & $7.83 \pm 0.11^{\mathrm{b}}$ & $7.90 \pm 0.14^{\mathrm{b}}$ \\
\hline $\mathrm{C} / \mathrm{N}$ ratio & $16.02 \pm 1.84^{\mathrm{a}}$ & $5.54 \pm 0.56^{\mathrm{b}}$ & $5.31 \pm 0.92^{\mathrm{b}}$ & $2.89 \pm 0.89^{\mathrm{b}}$ & $3.07 \pm 0.09^{\mathrm{b}}$ & $4.07 \pm 0.67^{\mathrm{b}}$ & $23.06 \pm 2.31^{\mathrm{c}}$ & $12.05 \pm 2.31^{\mathrm{a}}$ & $17.98 \pm 1.62^{\mathrm{d}}$ \\
\hline
\end{tabular}

Contents in $\%$ are based on a wet basis.

$\mathrm{TN}=$ Total nitrogen; $\mathrm{TS}=$ Total solids; $\mathrm{MC}=$ Moisture content $; \mathrm{VS}=$ Volatile solids; $\mathrm{C} / \mathrm{N}=$ Carbon to nitrogen $\pm \pm=$ Standard deviation $(\mathrm{n}=3)$.

${ }^{\mathrm{a}-\mathrm{f}}$ Means with unequal superscripts in a row shows significance difference at $\mathrm{p}<0.05$. 
both temperatures (Table 2). However, \% TS and \% VS were significantly decreased in all three manure categories $(p<0.05)$ while no significant effect of temperature was observed on $\%$ TS and \% VS. Moisture content $(\%)$ and $\mathrm{pH}$ were significantly increased in all the samples $(p<0.05)$, whereas $\mathrm{C} / \mathrm{N}$ ratio was not changed significantly. No significant decrease in $\mathrm{C} / \mathrm{N}$ ratio was observed at both mesophilic and thermophilic temperature with layers manure. In case of sow and Korean cattle manure, there is significant reduction in $\mathrm{C} / \mathrm{N}$ ratio after incubation $(\mathrm{p}<0.05)$. Sow manure showed no difference in decrease of $\mathrm{C} / \mathrm{N}$ ratio at both mesophilic and thermophilic setting, but more decrease of $\mathrm{C} / \mathrm{N}$ ratio in thermophilic setting was analyzed than that in mesophilic setting for cattle manure $(p<0.05)$.

This might be caused by the easily degradable $\mathrm{C}$ compounds present in manure. In addition, high moisture present in the cattle and sow manure may better distribute the $\mathrm{C}$ and $\mathrm{N}$ and thus induce higher degradation and rate of loss from partially anaerobic micro sites. This condition is more preferred for $\mathrm{N}_{2} \mathrm{O}$ emission rather than $\mathrm{CH}_{4}$ emission which requires highly anaerobic conditions (Velthof et al., 2003). Thus results obtained are in accordance with the previous research.

\section{Methane emissions and $B_{0, \mathrm{KM}}$ value}

The main factors affecting $\mathrm{CH}_{4}$ emissions in IPCC (1996) are the amount of manure produced and the portion of manure that decomposed anaerobically. The former depends on the rate of the waste production per animal and the number of animals, and the latter on how manure is managed. In addition, many studies have revealed that temperature had a strong influence on $\mathrm{CH}_{4}$ emissions of animal manure. Gupta et al. (2007) reported that the amount of $\mathrm{CH}_{4}$ produced during a storage period was affected by the ambient and heap temperature variations, which influences methanogenic bacterial growth and thus $\mathrm{CH}_{4}$ formation. Therefore, $\mathrm{CH}_{4}$ emission was studied at mesophilic temperatures in this study to simulate the field manure handling condition.

As seen in Table 3, the highest $\mathrm{CH}_{4}$ emissions were measured from Korean cattle manure, compared to sow and layers manure. In this study, $\mathrm{C} / \mathrm{N}$ ratio of fresh Korean cattle manure was 31.01, which was significantly higher than sow and layers manure (Table 1). Kulling et al. (2003) also reported the differences of $\mathrm{CH}_{4}$ emissions are caused by the carbon availability.

Emission estimation in IPCC (1996) uses variables such as the diversity and range of animal populations, as well as manure management practices among regions and countries. Hence, to get country specific $B_{0}$ value of manure in Korea $\left(\mathrm{B}_{0, \mathrm{KM}}\right)$ is essential to improve the estimation. Thus, in present work $\mathrm{B}_{0, \mathrm{KM}}$ was estimated from the manure of each livestock category in South Korea, following Tier 2 methodology. Current IPCC default $\mathrm{B}_{0}$ for Asia/Latin America (IPCC, 2006) and those obtained in this work are shown in Table 3 . The maximum $\mathrm{B}_{0}$ values from IPCC $(0.29$ and $0.39[ \pm 15 \%])$ for sow and layers respectively, in temperate climate are much higher than the maximum value obtained in this study. However, $\mathrm{B}_{0, \mathrm{KM}}$ value of $0.083 \mathrm{~m}^{3}$ $\mathrm{CH}_{4} \mathrm{~kg} \mathrm{VS}^{-1}$ for Korean cattle was comparable to IPCC value of $0.1( \pm 15 \%)$. A similar report by Gonzalez-Avalos and Ruiz-Suarez (2001) stated that methane emission factor was less than a factor of five than proposed IPCC value while estimating the methane emission from cattle manure in Latin America. The low $\mathrm{B}_{0}, \mathrm{KM}$ value in case of sow and layers may be due to the diet as methane emissions largely depends on the type of diet (Kumar et al., 2009,2013,2014). Feeding high forage diet leads to more methane emission compared to concentrate rich diet. It has been reported that in the US and European countries forage are fed in higher amount than concentrate, while Korean breeding circumstances gives more concentrate than forage diet. Further, Park et al. (2006) reported that methane conversion factor $(\mathrm{MCF}=0.39)$ recommended for climate with annual temperature $<15^{\circ} \mathrm{C}$, which is clearly an overestimate for cold climates with $\mathrm{MCF}<0.25$. The default $\mathrm{MCF}$ value are only laboratory based and have so far not been verified under field conditions.

\section{Effect of aeration on $\mathrm{N}_{\mathbf{2}} \mathrm{O}$ emission}

Nitrification is a necessary prerequisite for the emission of $\mathrm{N}_{2} \mathrm{O}$ and it depends upon the supply of oxygen. Therefore, in order to minimize the uncertainty in EF and mimic the manure management practices, effect of aeration for different time interval was studied for maximum $\mathrm{N}_{2} \mathrm{O}$ emission at ambient temperature and incubation period of more than 100 days.

It is clearly evident from the Figure 1 that $\mathrm{N}_{2} \mathrm{O}$ emission was higher $(0.049 \mathrm{~g})$ when $2 \mathrm{~L}$ air was provided at every $2 \mathrm{~h}$ interval, whereas when air was provided at $4,6,8,12$, and $16 \mathrm{~h}$ interval, emission was $0.005,0.004,0.002,0.003$, and $0.004 \mathrm{~g}$, respectively. Moreover, after 78 days of incubation $\mathrm{N}_{2} \mathrm{O}$ was either below the detectable limit or there is no emission at 4, 6, 8, 12, $16 \mathrm{~h}$ interval, whereas emissions consistently increased and reached up to $0.626 \mathrm{~g}$ after the complete storage period of 120 days with $2 \mathrm{~h}$ interval (data

Table 3. Comparisons of $\mathrm{B}_{0}$ from IPCC and this work in $\mathrm{m}^{3} \mathrm{CH}_{4} \mathrm{~kg} \mathrm{VS}^{-1}$ in Korea using Tier 2 methodology from IPCC, 2006

\begin{tabular}{lllc}
\hline Methane emission & Sow & Layers & Korean cattle \\
\hline $\mathrm{B}_{0, \mathrm{KM}}\left(\mathrm{m}^{3} \mathrm{~kg} \mathrm{VS}{ }^{-1}\right)$ from this study & 0.0579 & 0.0006 & 0.0828 \\
Default value $\left(\mathrm{B}_{0}\right)$ from IPCC & 0.29 & 0.39 & 0.1 \\
\hline
\end{tabular}




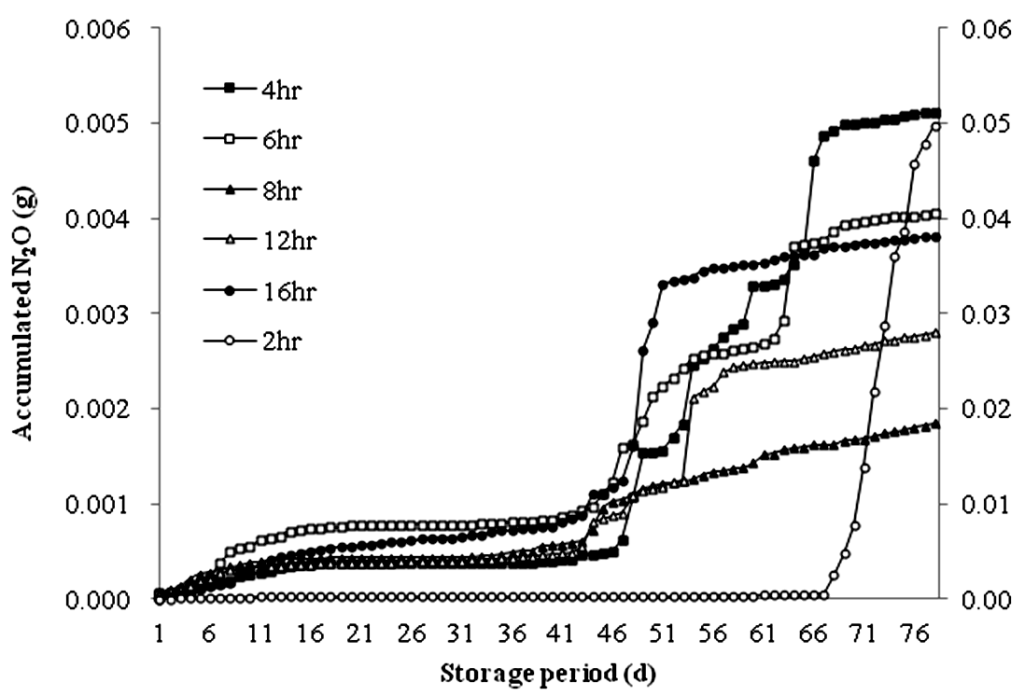

Figure 1. Accumulated $\mathrm{N}_{2} \mathrm{O}$ at different aeration cycles.

not shown). As $\mathrm{N}_{2} \mathrm{O}$ emission is attributed to the succeeding periods of mineralization, nitrification, and denitrification (Chadwick et al., 2000), organic $\mathrm{N}$ in manure has to be mineralized first and then transformed into nitrate and nitrite by nitrifiers. This requires a time for the reaction and proper oxygenic conditions. Further, maintaining the appropriate oxygenic condition is an important factor for complete nitrification and $\mathrm{N}_{2} \mathrm{O}$ emission. Since all the physico-chemical conditions are similar, lower $\mathrm{N}_{2} \mathrm{O}$ emissions when compared to that at $2 \mathrm{~h}$ interval was probably caused by incomplete nitrification.

\section{$\mathbf{N}_{2} \mathrm{O}$ emission and $\mathrm{EF}_{3(\mathrm{~s})}$}

When the cumulative $\mathrm{N}_{2} \mathrm{O}$ emission from $1 \mathrm{~kg}$ manure was compared in different temperatures $\left(37^{\circ} \mathrm{C}\right.$ and $\left.55^{\circ} \mathrm{C}\right)$, sow manure produced significantly $(\mathrm{p}<0.05)$ higher $\mathrm{N}_{2} \mathrm{O}$ at $37^{\circ} \mathrm{C}(0.26 \mathrm{~g})$ than at $55^{\circ} \mathrm{C}(0.01 \mathrm{~g})$. For layers manure, no difference in emission ( 0.028 and $0.027 \mathrm{~g}$ ) was observed at $37^{\circ} \mathrm{C}$ and $55^{\circ} \mathrm{C}$, respectively. However, $\mathrm{N}_{2} \mathrm{O}$ emissions were significantly higher $(0.49 \mathrm{~g})$ at $55^{\circ} \mathrm{C}$ compared to that at $37^{\circ} \mathrm{C}(0.19 \mathrm{~g})$ in Korean cattle manure. The results would be caused by the complex nature of $\mathrm{N}_{2} \mathrm{O}$ generation in manure, which may vary in response to the difference in characteristics of manure. According to Paul and Beauchamp (1989) and Kirchmann and Lundvall (1993), VS in the manure is easily metabolized by bacteria and induces to increase denitrification and/or immobilization of
$\mathrm{N}$, thus resulting in higher $\mathrm{N}_{2} \mathrm{O}$ emission. From Table 2, \% VS of sow was higher than that of layers and Korean cattle. In case of sow, emission was higher at $37^{\circ} \mathrm{C}$ in spite of similar \% VS loss at $37^{\circ} \mathrm{C}$ and $55^{\circ} \mathrm{C}$. The high pH of 8.13 at $55^{\circ} \mathrm{C}$ might have resulted in ammonia formation which has antagonistic relation with $\mathrm{N}_{2} \mathrm{O}$ release (Beck-Friis et al., 2000), resulting lower $\mathrm{N}_{2} \mathrm{O}$ emission. In case of layers manure, decrease in \% VS at both temperatures was low, low $\mathrm{N}_{2} \mathrm{O}$ emission. However, in Korean cattle significant decrease in \% VS was observed and the decrease was considerably higher at $55^{\circ} \mathrm{C}$. Because the $\mathrm{pH}$ of the manure at both mesophilic and thermophilic temperature was similar, VS would affect $\mathrm{N}_{2} \mathrm{O}$ emissions. In addition, Granli and Bockman (1994) reported the denitrification process increases at higher temperatures in accordance with this experimental result. Therefore, it could also be concluded that $\mathrm{N}_{2} \mathrm{O}$ emission is highly dependent on the $\% \mathrm{VS}$, as well as $\mathrm{pH}$ plays an important role.

To reflect a type of treatment for animal manure, $\mathrm{EF}_{3(\mathrm{~s})}$ ( $\mathrm{kg} \mathrm{N}_{2} \mathrm{O}-\mathrm{N} \mathrm{kg} \mathrm{N}{ }^{-1}$ ) were calculated for different livestock manure, taking aeration and temperature into account as per IPCC (1996). From the Table 4, $\mathrm{EF}_{3(\mathrm{~s})}\left(\mathrm{kg} \mathrm{N}_{2} \mathrm{O}-\mathrm{N} \mathrm{kg} \mathrm{N}{ }^{-1}\right)$ for sow at $37^{\circ} \mathrm{C}$ was 0.00127 which is the highest when compared to the value from layers and Korean cattle manure (0.00016 and 0.00113, respectively), but lower than the default emission factor $(0.01)$ for direct $\mathrm{N}_{2} \mathrm{O}$ emission from manure management suggested from IPCC GL (1996).

Table 4. Comparisons of $\mathrm{EF}_{3(\mathrm{~s})}$ from IPCC and this work in $\mathrm{kg} \mathrm{N}_{2} \mathrm{O}-\mathrm{N} \mathrm{kg} \mathrm{N}{ }^{-1}$

\begin{tabular}{lcccc}
\hline & & \multicolumn{2}{c}{$\mathrm{EF}_{3(\mathrm{~s})}\left(\mathrm{kg} \mathrm{N}_{2} \mathrm{O}-\mathrm{N} \mathrm{kg} \mathrm{N}^{-1}\right.$ excreted $)$} \\
\cline { 2 - 5 } Livestock category & \multirow{2}{*}{$37^{\circ} \mathrm{C}$} & $55^{\circ} \mathrm{C}$ & Natural aeration system & Forced aeration system \\
\cline { 2 - 4 } & & & 0.01 & 0.005 \\
Sow & 0.00127 & 0.00008 & \\
Koyers & 0.00016 & 0.00015 & \\
\hline
\end{tabular}


Table 5. Comparisons of $\mathrm{N}_{\mathrm{ex}(\mathrm{T})}$ from IPCC and this work in $\mathrm{kg} \mathrm{N} \mathrm{yr}^{-1}$

\begin{tabular}{|c|c|c|c|c|c|c|c|}
\hline \multirow[b]{2}{*}{$\begin{array}{r}\text { Livestock } \\
\text { category }\end{array}$} & \multirow{2}{*}{\multicolumn{2}{|c|}{ Manure $\mathrm{kg} \mathrm{d}^{-1}$}} & \multicolumn{4}{|c|}{ N value* } & \multirow{2}{*}{$\begin{array}{l}\text { IPCC } 1996 \\
\mathrm{~kg} \mathrm{~N} \mathrm{yr}^{-1}\end{array}$} \\
\hline & & & $\mathrm{N} \%$ & $\mathrm{~kg} \mathrm{~N} \mathrm{~d}^{-1}$ & $\mathrm{~kg} \mathrm{~N} \mathrm{yr}^{-1}$ & $\begin{array}{c}\mathrm{kg} \mathrm{N} \mathrm{yr}^{-1} \\
\text { (Dung+Urine) }\end{array}$ & \\
\hline \multirow[t]{2}{*}{ Sow } & Dung & $0.89 \pm 1.2$ & $0.96 \pm 0.02$ & 0.008 & 2.92 & 7.67 & 20 \\
\hline & Urine & $1.74 \pm 0.6$ & $0.80 \pm 0.01$ & 0.013 & 4.75 & & \\
\hline Layers & Dung & $124.7 \pm 0.6(\mathrm{~g})$ & $1.39 \pm 0.01$ & $1.73(\mathrm{~g})$ & 0.63 & 0.63 & 0.6 \\
\hline \multirow[t]{2}{*}{ Korean cattle } & Dung & $8.8 \pm 3.1$ & $0.50 \pm 0.05$ & 0.044 & 16.06 & 28.19 & 70 \\
\hline & Urine & $6.1 \pm 2.4$ & $0.68 \pm 0.37$ & 0.031 & 11.13 & & \\
\hline
\end{tabular}

* $\mathrm{N}$ value was taken from National Institute of Animal Science.

Similarly, $\mathrm{EF}_{3(\mathrm{~s})}$ for Korean cattle was maximum (0.00189) at $55^{\circ} \mathrm{C}$ but far lower than the IPCC default value of either natural aeration system $(0.01)$ or forced aeration system (0.005).

\section{Annual average nitrogen excretion rates, $\mathbf{N}_{\mathbf{e x}(\mathrm{T})}$}

Annual average excretion rate was determined for the sow, layers and Korean cattle using the typical average animal mass for livestock category and \% $\mathrm{N}$ values, obtained from the National Institute of Animal Sciences, South Korea. As seen in Table 5, it is clear that default $\mathrm{N}_{\mathrm{ex}(\mathrm{T})}$ value ( $\mathrm{kg} \mathrm{N} \mathrm{yr}^{-1}$ ) obtained from IPCC (1996) is nearly 2.5 fold higher than that of obtained value for sow and Korean cattle but similar for layers. The possible reason for lower $\mathrm{N}_{\mathrm{ex}(\mathrm{t})}$ is lower manure production by Korean cattle (14 to $15 \mathrm{~kg} / \mathrm{d}$ ) compared to that of European cattle (18 to 25 $\mathrm{kg} / \mathrm{d}$ ) (Menzi et al., 1998).

\section{CONCLUSIONS}

As introduced in IPCC (1996), this research was conducted to obtain the essential values; i.e., $\mathrm{B}_{0, \mathrm{KM}}$ value for $\mathrm{CH}_{4}$ emission, $\mathrm{EF}_{3(\mathrm{~s})}$ and $\mathrm{N}_{\mathrm{ex}(\mathrm{T})}$ values for $\mathrm{N}_{2} \mathrm{O}$ in order to construct the typical Korean specific GHG inventory. According to animal species (sow, layers, and Korean cattle), $\mathrm{CH}_{4}$ and $\mathrm{N}_{2} \mathrm{O}$ emissions were very different each other and the increase of $\mathrm{C} / \mathrm{N}$ ratio induced higher $\mathrm{CH}_{4}$ emission. \% VS loss and $\mathrm{pH}$ played important role in $\mathrm{N}_{2} \mathrm{O}$ emission which was higher at higher temperature. Consequently, the obtained basic values were mostly much less than the proposed values by the IPCC except $\mathrm{B}_{0, \mathrm{KM}}$ value for Korean cattle and $\mathrm{N}_{\mathrm{ex}(\mathrm{T})}$ value for layers.

The values obtained will affect the calculation of $\mathrm{CH}_{4}$ and $\mathrm{N}_{2} \mathrm{O}$ emission factors from manure and will serve as a reference to construct the country specific GHG inventory. Further, field experiments will warrant for the verification of the laboratory results and more accurate estimates of actual $\mathrm{CH}_{4}$ and $\mathrm{N}_{2} \mathrm{O}$ emission, and the present work will be expected to pave the way to build the country specific GHG inventory.

\section{ACKNOWLEDGEMENT}

We are grateful to the funding by Rural Development Administration, Korea.

\section{REFERENCES}

Amon, B., T. Amon, J. Boxberger, and C. Alt. 2001. Emissions of $\mathrm{NH}_{3}, \mathrm{~N}_{2} \mathrm{O}$ and $\mathrm{CH}_{4}$ from dairy cows housed in a farmyard manure tying stall (housing, manure storage, manure spreading). Nutr. Cycl. Agroecosys. 60:103-113.

Beck-Frii, B., M. Pell, U. Sonesson, H. Jonsson, and H. Kirchmann. 2000. Formation and emission of $\mathrm{N}_{2} \mathrm{O}$ and $\mathrm{CH}_{4}$ from compost heaps of organic household waste. Environ. Monit. Assess. 62:317-331.

Blanes-Vidal, V., M. N. Hansen, S. Pedersen, and H. B. Rom. 2008. Emissions of ammonia, methane and nitrous oxide from pig houses and slurry: Effect of rooting material, animal activity and ventilation flow. Agric. Ecosys. Environ. 124:237244.

Brown, H. A., C. Wagner-Riddle, and G. W. Thurtell. 2002. Nitrous oxide flux from a solid manure pile measured using a micrometerorological mass balance method. Nutr. Cycl. Agroecosys. 62:53-60.

Chadwick, D. R., B. F. Pain, and S. K. E. Brookman. 2000. Nitrous oxide and methane emissions following application of animal manures to grassland. J. Environ. Qual. 29:277-287.

Cho, C-S., J-H. Sa, K-K. Lim, T-M. Youk, S-J. Kim, and E-C. Jeon. 2012. Development of methane and nitrous oxide emission factors for the biomass fired circulating fluidized bed combustion power plant. Sci. World J Article ID 989249. 9 p. http://dx.doi.org/10.1100/2012/989242

EPA. 1998. Field Evaluation of EPA Method 0040 (Volatiles using bags). EPA/600/SR-98/030. p. 2.

EPA. 1981. Anaerobic Fermentation of Beef Cattle Manure. p. 1108.

FAO. 2003. World Agriculture: towards 2015/2030. An FAO perspective. Food and Agriculture Organization, Rome, p. 97.

Forster, P., V. Ramaswamy, P. Artaxo, T. Berntsen, R. Betts, D. W. Fahey, J. Haywood, J. Lean, D.C. Lowe, G. Myhre, J. Nganga, R. Prinn, G. Raga, M. Schulz, and R. Van Dorland. 2007. Changes in atmospheric constituents and in radiative forcing. In: Climate Change 2007: The Physical Science Basis. Contribution of Working Group I to the Fourth Assessment Report of the Intergovernmental Panel on Climate Change (Ed. S. Solomon, D. Qin, M. Manning, Z. Chen, M. Marquis, K. B. 
Averyt, M. Tignor, and H. L. Miller). Cambridge, UK, Cambridge University Press.

Garg, A., S. Bhattacharya, P. R. Shukla, and V. R. Dadhwal. 2001. Regional and sectoral assessment of greenhouse gas emissions in India. Atmos. Environ. 35:2679-2695.

Gonzalez-Avalos, E. and L. G. Ruiz-Suarez. 2001. Methane emission factor from cattle manure in Mexico. Bioresour. Technol. 80:63-71.

Granli, T. and O. C. Bockman. 1994. Nitrous oxide from agriculture. Norw. J. Agric. Sci. Suppl. 12:1-127.

Gupta, P. K., A. K. Jha, S. Koul, P. Sharma, V. Pradhan, V. Gupta, C. Sharma, and N. Singh. 2007. Methane and nitrous oxide emission from bovine manure management practices in India. Environ. Pollut. 146:219-224.

IPCC. 1996. Climate change 1995. In: The Science of Climate Change (Ed. J. T. Houghton et al.). Cambridge University Press, UK.

IPCC. 2006. Emission from livestock and manure management. In: Guidelines for National Greenhouse Gas Inventories, Prepared by National Greenhouse Gas Inventories Programme (Ed. S. Eggleston et al.). IGES, Japan.

Kirchmann, H. and A. Lundvall. 1993. Relationship between N immobilization and volatile fatty acids in soil after application of pig and cattle slurry. Biol. Fertil. Soils. 15:161-164.

Kulling, D. R., H. Menzi, F. Sutter, P. Lischer, and M. Kreuzer. 2003. Ammonia, nitrous oxide and methane emissions from differently stored dairy manure derived grass and hay- based rations. Nutr. Cycl. Agroecosys. 65:13-22.

Kumar, S., A. K. Puniya, M. Puniya, S. S. Dagar, S. K. Sirohi, K. Singh, and G. W. Griffith. 2009. Factors affecting rumen methanogens and methane mitigation strategies. World J. Microbiol. Biotechnol. 25:1557-1566.

Kumar, S., P. K. Choudhury, M. D. Carrod, G. W. Griffith, S. S Dagar, M. Puniya, S. Calabro, S. R. Ravella, T. Dhewa, R. C. Upadhyay, S. K. Sirohi, S. S. Kundu, M. Wanapat, and A. K. Puniya. 2014. New aspects and strategies for methane mitigation from ruminants. Appl. Microbiol. Biotechnol. 98:31-44.

Kumar, S., S. S. Dagar, S. K. Sirohi, R. C. Upadhyay, and A. K. Puniya. 2013. Microbial profiles, methanogenesis and digestibility in vitro based on varying concentrations of roughage. Ann. Microbiol. 63:541-545.

Loyon, L., F. Guiziou, and P. Saint Cast. 2008. Impact of manure management of different livestock on gaseous emissions: laboratory study. Aust. J. Exp. Agric. 48:128-131.

Lu, R. D., Y. E. Li, F. Shi, and Y. F. Wan. 2008. Effect of compost on the greenhouse gases emission from dairy manure. J. AgroEnviron. Sci. 27:1235-1241.

Moss, A. R., J. P. Jouany, and J. Newbold. 2000. Methane production by ruminants: Its contribution to global warming. Ann. Zootech. 49:231-253.

Menzi, H., B. Pain, and K. Smith. 1998. Solid Manure in Europe. Results of a survey by the working group on solid manure of RAMIRAN. In: Proceedings of the 8th International Conference on Management Strategies for Organic Waste Use in Agriculture, Rennes, France.

Nouchi, I., S. Mariko, and K. Aoki. 1990. Mechanism of methane transport from the rhizosphere to the atmosphere through rice plants. Plant Physiol. 94:59-66.
Park, K. H., G. T. Andrew, M. Michele, C. Karen, and W. Claudia. 2006. Greenhouse gas emissions from stored liquid swine manure in a cold climate. Atmos. Environ. 40:618-627.

Paul, J. W. and E. G. Beauchamp. 1989. Effect of carbon constituents in manure on denitrification in soil. Can. J. Soil Sci. 69:49-61.

Petersen, S. O., A. M. Lind, and S. G. Sommer. 1998. Nitrogen and organic matter losses during storage of cattle and pig manure. J. Agric. Sci. 130:69-79.

Robinson, J. A., W. J., Smolemski, M. L. Ogilvie, and J. P. Peters. 1989. In vitro total gas, $\mathrm{CH}_{4}, \mathrm{H}_{2}$, volatile fatty acids and lactate kinetics studies on luminal contents from small intestine, cecum and colon of pig. Appl. Environ. Microbiol. 55:24602467.

Safley Jr., L.M., M. E. Casada, J. W. Woodbury, and K. F. Roos. 1992. Global methane emission from livestock and poultry manure. USEPA Report 400/1-91/048. USEPA, Washington, DC

Smith, K. A., A. J. Brewer, J. Crabb, and A. Dauven. 2001. A survey of the production and use of animal manure in England and Wales. III. Cattle manure. Soil Use Manage. 17:77-87.

Sorai, M., N. Yoshida, and M. Ishikawa. 2007. Biogeochemical simulation of nitrous oxide cycle based on the major nitrogen processes. J. Geophys. Res. 112:G1. http://dx.doi.org/10.029/ 2005JG000109.

SPSS, Inc. 1996. Systat version 6.0.1.

Steinfeld, H., P. Gerber, T. Wassenaar, V. Castel, M. Rosales, and C. de Haan. 2006. Livestock's Long Shadow: Environmental Issues and Options. Food and Agricultural Organization, UN, Rome.

Steven, C. E. and I. D. Hume. 1995. Comparative Physiology of the Vertebrate Digestive System. Cambridge University Press, Cambridge.

Sukahara, T. and K. Ushida. 2000. Effects of animal and plant protein on cecal fermentation in guinea pigs (Cavia porclellus), rats (Rattus norvegicus) and chicks (Gallus gallus domesticus). Comp. Biochem. Physiol. A. Mol. Integr. Physiol. 127:139-146.

Velthof, G. L., P. J. Kuikman, and O. Oenema. 2003. Nitrous oxide emission from animal manures applied to soil under controlled conditions. Biol. Fertil. Soils 37:221-230.

Wang, J., C. Duan, Y. Ji, and Y. Sun. 2010. Methane emissions during storage of different treatments from cattle manure in Tianjin. J. Environ. Sci. 22:1564-1569.

Wang, S-H. and D-J. Huang. 2005. Assessemnt of greenhouse gas emissions from poultry enteric fermentation. Asian-Aust. J. Anim. Sci. 18:873-878.

Yamaji, K., T. Ohara, and H. Akimoto. 2003. A country specific high resolution emission inventory for methane from livestock in Asia in 2000. Atmos. Environ. 37:4393-4406.

Yamulki, S. 2006. Effect of straw addition on nitrous oxide and methane emissions from stored farmyard manures. Agric. Ecosys. Environ. 112:140-145.

Yamulki, S., S. C. Jarvis, and P. Owen. 1999. Methane emission and uptake from soils as influenced by excreta deposition from grazing animals. J. Environ. Qual. 28:676-682.

You, Y. B., H. M. Dong, Z. P. Zhu, X. P. Tao, and Y. X. Chen. 2008. Experiments on influencing factors of methane emissions from beef cattle manure stack. Trans. CSAE 24:168-172. 